\title{
Accurate diagnoses, evidence based drugs, and new devices (3 Ds) in heart failure
}

\author{
Bambang B. Siswanto ${ }^{1,2}$ \\ ${ }^{1}$ Dept. of Cardiology \& Vascular Medicine, Faculty of Medicine, Universitas Indonesia, Jakarta, Indonesia \\ ${ }^{2}$ National Cardiovascular Center Jakarta, Indonesia
}

\begin{abstract}
Abstrak
Gagal jantung menjadi masalah utama dalam bidang kardiologi karena bertambahnya jumlah penderita dan seringnya rawat ulang serta kematian dan kecacatan. Penyebab meningkatnya masalah gagal jantung adalah: (1) Keberhasilan penanganan serangan akut miokard infark yang berhasil menyelamatkan nyawa namun kecacatannya menyebabkan gagal jantung. (2) Bertambahnya jumlah orang yang mencapai usia lanjut sedangkan pada usia lanjut akan terjadi gagal jantung karena perjalanan usia. (3) Masih tingginya kejadian infeksi di Indonesia yang dapat menyebabkan penyakit jantung reumatik pasca infeksi Streptococcus beta hemolitikus, infeksi virus yang menyebabkan miokarditis, infeksi yang menyebabkan endokarditis serta tuberkulosis yang menyebabkan pericarditis tuberkulosa. (4) Masih seringnya ditemukan faktor faktor risiko penyakit jantung koroner seperti banyaknya perokok, diabetes, hiperkolesterolemia, hipertensi dan obesitas. Indonesia ikut dalam pendataan international multi senter pada tahun 2006. Acute Decompensated HEart failure REgistry adalah suatu pendataan international menggunakan web yang mendata pasien dengan acute decompensated heart failure yang masuk dan dirawat di unit gawat darurat. Dari data di 5 rumah sakit besar di pulau Jawa dan Bali yang ikut dalam pendataan ini didapatkan bahwa usia gagal jantung lebih muda, pasien datang lebih parah dan terlambat, lama rawat rata rata 7 hari, dan angka kematian di rumah sakit 6,7\%. Makalah ini bertujuan memberikan ringkasan hal hal yang penting dalam diagnosis dan tata laksana gagal jantung. Tiga D (diagnosis cepat tepat, drugs yang berbasis bukti dan devices baru) adalah penting pada gagal jantung, selain itu apa yang harus dikerjakan dan jangan dikerjakan dalam menghadapi gagal jantung juga harus diperhatikan. (Med J Indones 2012;21:52-8)
\end{abstract}

\begin{abstract}
Heart failure becomes main problem in cardiology because of increasing of heart failure patients, rehospitalization rate, morbidity, and mortality rate. The main causes of increasing heart failure problems are: (1) Successful treatment of acute myocardial infarction can be life saving, but its sequelae can cause heart failure. (2) Increasing life expectancy rate grows along with incidences of ageing related heart failure. (3) High prevalence of infection in Indonesia can cause rheumatic heart disease post Streptococcal beta hemolyticus infection, viral myocarditis, infective endocartitis, and tuberculoid pericarditis. (4) Many risk factors for coronary heart disease are often found in heart failure patients, for examples smoking, diabetes, hypercholesterolemia, hypertension, and obesity. Indonesia joined international multicentered registry in 2006. Acute Decompensated HEart failure REgistry is a web based international registry to record patient with acute decompensated heart failure treated in emergency room. It was found that heart failure patients in 5 big hospitals in Java and Bali island that joined this registry are younger, sicker and late to seek treatment. The median hospital length of stay was 7 days and in hospital mortality rate was $6.7 \%$. The aim of this article is to give summary about essential things in diagnosing and treating heart failure patients. 3D (accurate diagnoses, evidence based drugs, and new devices) are the most important but what to do and what not to do in dealing with heart failure is also useful for your daily practice. (Med J Indones 2012;21:52-8)
\end{abstract}

Keywords: Devices, diagnostic, drugs, heart failure

\section{Heart failure situation in Indonesia}

Recently, heart failure had become the most prevalence of heart disease in Indonesia because of some reasons: (1) The success treatment of Acute Myocardial Infarction really prevent mortality but become systolic heart failure. (2) The increasing life expectancy leads to ageing heart that resulted in diastolic heart failure. (3) In Indonesia, where the infectious disease is still prominent, the prevalence of valvular heart disease also increases. Uncontrolled hypertension, bad life style including unhealthy food, viral myocarditis and other infection, also contribute in increasing number of heart failure, admission and mortality. (4) Uncontrolled CAD risk factors in Indonesia people as manifested by some trends of increasing hypertension, smokers, uncontrolled pregnancy and hypercholesterolemia.
In 2005 Siswanto et al. found that at 6 months follow up the mortality rate $12 \%$ and the readmission rate $29 \%{ }^{1}$ In 2006 Indonesia involved in the International Acute Decompensated HEart failure REgistry (ADHERE) involving 5 hospitals in Java and Bali island. A total of 1687 patients with Acute Decompensated Heart Failure were admitted at the emergency room and registered using web base international software, mean age was 60 years, $64.5 \%$ male. Compared to other countries (Asia Pasific, Europe, US), Indonesian patients were sicker, had more severe symptoms, lower ejection fraction, as well as higher in-hospital mortality (6.7\%). On admission, only $68 \%$ got ACE-I/ARB and $41 \%$ got low dose beta blocker. Although the hospitalization rate keep increasing each year, only 33.5\% got covered by health insurance. ${ }^{2}$ 


\section{Ds in heart failure}

The primary care physician typically care for 2000 patients. It is likely to have $40-50$ patients with heart failure (more if population is elderly) and to have 5 or so new cases of heart failure diagnosed each year, with the diagnosis of suspected heart failure in perhaps 3 times as many. Clear guidance is needed on which clinical features and combination of investigations is best to rule out or rule in heart failure in patients with new symptoms. ${ }^{3}$ Ds is an easy way to remember important things when dealing with heart failure.

\section{1. (D)iagnostic accuracy}

Accurate and early diagnosis is important since it is a prerequisite before early treatment. Only $26 \%$ of patients with suspected heart failure referred to a rapid access for echocardiography and the diagnosis confirmed after investigation.

"Rule of half" in heart failure may occur. Only half of $\mathrm{HF}$ patients are diagnosed correctly. Half of the correctly diagnosed were treated not according to the guidelines; the drugs that had been used were not evidence-based and the dose that should be used were too low. Half of the etiology of HF are not assessed and not appropriately corrected. Half of the HF that we managed were readmitted and dead in 4 years follow up.

HF is a syndrome with typical symptoms of shortness of breath on excertion, signs of fluids retention (pulmonary congestion, ankle swelling, ascites and liver enlargement), and proven by objective evidence of abnormal structure and function (cardiomegaly, third heart sound, cardiac murmur, abnormal echocardiogram and abnormal natriuretic peptide). In a community without echocardiography, Framingham Heart Failure Criteria for diagnosis may be applied. Minor criteria are acceptable only if they can not be attributed to another medical condition (such as pulmonary hypertension, chronic lung disease, cirrhosis, ascites, or nephrotic syndrome). Clinical congestive heart failure is diagnosed when 2 major criteria present or 1 major and two minors present. The Modified Framingham Heart Study criteria are $100 \%$ sensitive and $78 \%$ specific for identifying persons with definite congestive heart failure. $^{4}$

Due to the low specificity of the clinical criteria, considerations must be thought for excluding differential diagnosis. An electrocardiogram should be performed in every patients with suspected heart failure. An abnormal ECG has a predictive value for the presence of HF. If the ECG is completely normal, $\mathrm{HF}$, especially with systolic dysfunction is unlikely (< $10 \%)$. CXR is an essential component of the diagnostic work up in heart failure. It permits assessment of pulmonary congestion and may demonstrate important pulmonary or cardiac causes of dyspnoea. The chest $\mathrm{X}$ ray (in two planes) is useful to detect cardiomegaly, pulmonary congestion and pleural fluid accumulation and can demonstrate the presence of pulmonary disease or infection causing or contributing to dyspnea. Apart from congestion, findings are predictive of HF only in the context of typical signs and symptoms. In acute heart failure, cardiomegaly may be absent. ${ }^{5}$

If an electrocardiogram (ECG), chest $\mathrm{X}$ ray and blood levels of B-natriuretic peptide (BNP) or N-terminal pro-B-type natriuretic peptide (NTproBNP) are within normal limits, an alternative cause must be considered. Unfortunately, biomarkers usage is still very limited in Indonesia, although point of care NTproBNP available. $\mathrm{BNP} / \mathrm{NT}$ proBNP accurately rule out/ rule in HF.

Framingham criteria for the diagnosis of congestive heart failure

\author{
Major Criteria \\ Paroxysmal nocturnal dyspnea or orthopnea \\ Neck vein distension \\ Crackles ( $\pm 10 \mathrm{~cm}$ from the base of the lung) \\ Cardiomegaly on chest radiograph \\ Acute pulmonary edema \\ $\mathrm{S}_{3}$ gallop \\ Weight loss $\geq 4.5 \mathrm{~kg}$ caused by CHF treatment
}

\author{
Minor Criteria \\ Ankle edema \\ Night cough \\ Dyspnea on exertion \\ Hepatomegaly \\ Pleural effusion \\ Tachycardia $\geq 120$ beats $/ \mathrm{min}$ \\ Weight loss $\geq 4.5 \mathrm{~kg}$ caused by CHF treatment where factors other \\ than treatment of CHF could have contributed to the weight loss \\ can be excluded
}

Venous pressure $\geq 16 \mathrm{~cm} \mathrm{H}_{2} \mathrm{O}$ 


\section{2. (D)rugs that's proven by $E B M$}

DO follow the guideline in treating heart failure. After accurate diagnosis, classify heart failure patients structurally (according to ACC/AHA) or by symptoms relating to functional capacity (NYHA) and treat accordingly with evidence-based drugs. ${ }^{6}$

ACE-inhibitors remain a cornerstone in the treatment of HF which can improve both morbidity and mortality in all grades of symptomatic heart failure with systolic dysfunction and can delay or prevent progression of asymptomatic to symptomatic heart failure. More recently, researches have shown the prognostic benefits of treatment with $\beta$ blockers in heart failure with left ventricular systolic dysfunction. Unfortunately, heart failure is difficult to diagnose accurately on clinical grounds in some cases, so we need biomarker or echocardiography.

Figure 1 represents the guideline to classify the diagnosis of HF and table 1 and 2 show some evidencebased medications according to ACC/AHA guidelines.

\section{3. (D)evice in appropriate patients}

Despite the emergence of new devices in the armamentarium of chronic heart failure management, mostly their usage is limited for those with advanced heart failure who have no improvement after optimal medical therapy, according to ESC 2008 Heart Failure guideline. ${ }^{5}$ Figure 2 depicts algorhythm in the management of heart failure, including the use of some devices. Devices including CRT (Cardiac Resynchronization Therapy), ICD (Implantable Cardioverter Defibrilator), and LVAD (Left Ventricular Assited Devices)

\section{What's new in 2011?}

The MADIT-II (Multicentre Automatic Defibrillator Implantation Trial II) trial was the first major study to show a survival benefit for prophylactic ICD implantation in patients with previous MI and a left ventricular ejection fraction (LVEF) of less than $30 \% .{ }^{8}$ Most of the primary prevention ICD trials have focused on patients with ischaemic etiology of HF. The previous SCD-HeFT (Sudden Cardiac Death in Heart Failure Trial) study, which also enrolled patients with non-ischaemic cardiomyopathy (NICM). ${ }^{9}$ This showed a similar relative risk reduction of death of $27 \%$ in the NICM group as compared to $21 \%$ in the ischaemic group. Nevertheless, the absolute risk reduction over five years was only a modest $7.2 \%$ so this was cited as a possible reason as to why the National Institute for Health and Clinical Excellence (NICE) have not issued specific guidance on implantation of an ICD in the nonischaemic population.

\section{At Risk for Heart Failure}

\begin{tabular}{|l|}
$\begin{array}{c}\text { Stage A } \\
\text { At high risk for HF but } \\
\text { without structural } \\
\text { heart disease or } \\
\text { symptoms of HF. }\end{array}$ \\
$\begin{array}{l}\text { e.g.: Patients with: } \\
\text {-hypertension } \\
\text {-atherosclerotic } \\
\text { disease } \\
\text {-diabetes } \\
\text {-metabolic syndrome } \\
\text { Patients or } \\
\text {-using cardiotoxins } \\
\text {-with HFx CM }\end{array}$ \\
\multicolumn{1}{c}{ Therapy } \\
Goals \\
-Treat hypertension \\
-Encourage smoking \\
cessation \\
-Treat lipid disorders \\
-Encourage regular \\
exercise \\
-Discourage alcohol \\
intake, illicit drug use \\
-Control metabolic \\
syndrome \\
Drugs \\
-ACEl or ARB in \\
appropriate patients \\
(see text) for vascular \\
disease or diabetes
\end{tabular}

\section{Heart Failure}

Stage C
Structural heart
disease with prior or
current symptoms
of HF.

e.g.: Patients with:

-known structura

heart disease and

-shortness of breath

and fatigue, reduced

exercise tolerance

-asymptomatic

valvular disease

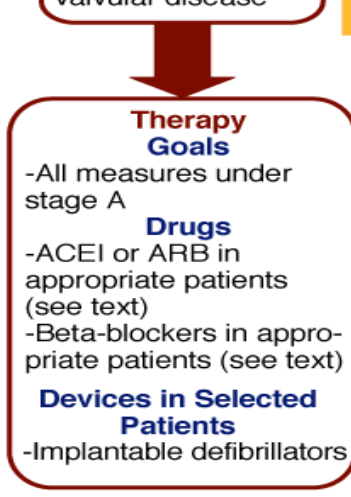

\section{} Structural heart disease but without symptoms of HF.

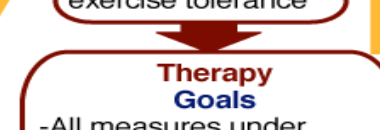

-All measures under

stages $A$ and $B$

-Dietary salt restriction

Drugs for Routine Use

-Diuretic for fluid retention

-ACEI

-Beta-blockers

Drugs in Selected Patients

-Aldosterone antagonist

-ARBs

-Digitalis

-Hydralazine/nitrates

Devices in Selected Patients

-Biventricular pacing

-Implantable defibrillators

\section{Stage D Refractory HF requiring specialized interventions.}

\section{e.g.: Patients} who have marked symptoms at rest despite maximal medica therapy (e.g., those who are recurrently hospitalized or cannot be safely discharged from the hospital without specialized interventions)

Therapy
Goals
-Appropriate measures
under stages A, B, C
-Decision re: appropriate
level of care
Options
-Compassionate end-of-
life care/hospice
-Extraordinary measures
-heart transplant
-chronic inotropes
-permanent mechanical
support
-experimental surgery or
drugs

Figure 1. ACC/AHA classification of heart failure ${ }^{7}$ 
Table 1. Cardiovascular medications useful for treatment of various stages of heart failure

\begin{tabular}{|c|c|c|c|}
\hline Drug & Stage A & Stage B & Stage C \\
\hline \multicolumn{4}{|l|}{ ACE Inhibitors } \\
\hline Captopril & $\mathrm{H}, \mathrm{DN}$ & Post MI & $\mathrm{HF}$ \\
\hline Enalapril & $\mathrm{H}, \mathrm{DN}$ & Asymptomatic LVSD & $\mathrm{HF}$ \\
\hline Fosinopril & $\mathrm{H}$ & - & $\mathrm{HF}$ \\
\hline Lisinopril & $\mathrm{H}, \mathrm{DN}$ & Post MI & $\mathrm{HF}$ \\
\hline Perindopril & H, CV Risk & - & - \\
\hline Quinapril & $\mathrm{H}$ & - & $\mathrm{HF}$ \\
\hline Ramipil & H, CV Risk & Post MI & Post MI \\
\hline Trandolapril & $\mathrm{H}$ & Post MI & Post MI \\
\hline \multicolumn{4}{|c|}{ Angiotensin Receptor Blockers } \\
\hline Candesartan & $\mathrm{H}$ & - & $\mathrm{HF}$ \\
\hline Eprosartan & $\mathrm{H}$ & - & - \\
\hline Irbesartan & $\mathrm{H}, \mathrm{DN}$ & - & - \\
\hline Losartan & $\mathrm{H}, \mathrm{DN}$ & CV Risk & - \\
\hline Olmesartan & $\mathrm{H}$ & - & - \\
\hline Telmisartan & $\mathrm{H}$ & - & - \\
\hline Valsartan & $\mathrm{H}, \mathrm{DN}$ & Post MI & Post MI, HF \\
\hline \multicolumn{4}{|l|}{ Aldosterone Antagonists } \\
\hline Eplerenone & $\mathrm{H}$ & Post MI & Post MI \\
\hline Spironolactone & $\mathrm{H}$ & - & $\mathrm{HF}$ \\
\hline \multicolumn{4}{|l|}{ Beta Blockers } \\
\hline Acebutolol & $\mathrm{H}$ & - & - \\
\hline Atenolol & $\mathrm{H}$ & Post MI & - \\
\hline Bisoprolol & $\mathrm{H}$ & - & $\mathrm{HF}$ \\
\hline Carvedilol & $\mathrm{H}$ & Post MI & HF, Post MI \\
\hline Labetalol & $\mathrm{H}$ & - & - \\
\hline Metoprolol succinate & $\mathrm{H}$ & - & Hf \\
\hline Metoprolol tartrate & $\mathrm{H}$ & Post MI & - \\
\hline Nadolol & $\mathrm{H}$ & - & - \\
\hline Penbutolol & $\mathrm{H}$ & - & - \\
\hline Pindolol & $\mathrm{H}$ & - & - \\
\hline Propranolol & $\mathrm{H}$ & Post MI & - \\
\hline Timolol & $\mathrm{H}$ & Post MI & - \\
\hline Digoxin & - & - & $\mathrm{HF}$ \\
\hline
\end{tabular}

CV Risk indicates reduction in future cardiovascular events; DN, diabetic nephropathy; H, hypertension; HF, heart failure; Asymptomatic LVSD, Asymptomatic left ventricular systolic dysfunction; Post MI, reduction in heart failure or other cardiac events following myocardial infarction.

The CARE-HF (Cardiac Resynchronisation - Heart Failure) study was pivotal being the first to show that a CRT device without a defibrillator could reduce the risk of death from any cause by $36 \%$, when compared to standard medical therapy. Crucially, a number of important patient groups were excluded from this seminal trial, such as those with permanent atrial fibrillation (AF), mild HF symptoms (New York Heart Association [NYHA] functional class I and II), or a narrow QRS duration $(<120 \mathrm{msec})$. The challenging task is to seek evidence for implanting CRT in these selective populations. ${ }^{10}$

When considering $\mathrm{AF}$, a large Italian cohort study has reported improvements in LVEF, NYHA class and exercise capacity, similar to those seen in sinus rhythm, when CRT is combined with AV node ablation. Nevertheless, there is consensus that there is insufficient evidence to support a mortality benefit with this strategy, and more prospective randomised studies are necessary.

The most compelling evidence for use of CRT in patients with mild HF symptoms comes from the MADIT-CRT (Multicentre Automatic Defibrillator Implantation Trial with Cardiac Resynchronisation Therapy) study, which enrolled patients in NYHA class I and II and randomised to ICD or CRT-D. This showed a $41 \%$ reduction in the risk of HF-events in the CRT-D group, which was primarily evident in a prespecified group of patients with significant electrical dysynchrony (QRS $>150 \mathrm{msec}) .{ }^{11}$

To anticipate the overwhelming wave of euphoria in device implantation for chronic heart failure, the ESC issued a focused update on device therapy for heart 
Table 2. Oral diuretics recommended for use in the treatment of fluid retention in chronic heart failure

\begin{tabular}{|c|c|c|c|}
\hline Drug & $\begin{array}{c}\text { Initial } \\
\text { Daily Dose(s) }\end{array}$ & $\begin{array}{l}\text { Maximum Total } \\
\text { Daily Dose }\end{array}$ & $\begin{array}{l}\text { Duration } \\
\text { of Action }\end{array}$ \\
\hline Loop diuretics & & & \\
\hline Burnetanide & 0.5 to $1.0 \mathrm{mg}$ once or twice & $10 \mathrm{mg}$ & 4 to 6 hours \\
\hline Furosemide & 20 to $40 \mathrm{mg}$ once or twice & $600 \mathrm{mg}$ & 6 to 8 hours \\
\hline Torsemide & 10 to $20 \mathrm{mg}$ once & $200 \mathrm{mg}$ & 12 to 16 hours \\
\hline Thiazide diuretics & & & \\
\hline Chlorothiazide & 250 to $500 \mathrm{mg}$ once or twice & $1000 \mathrm{mg}$ & 6 to 12 hours \\
\hline Chlorthalidone & 12.5 to $25 \mathrm{mg}$ once & $100 \mathrm{mg}$ & 24 to 72 hours \\
\hline Hydrochlorothiazide & $25 \mathrm{mg}$ once or twice & $200 \mathrm{mg}$ & 6 to 12 hours \\
\hline Indapamide & 2.5 once & $5 \mathrm{mg}$ & 36 hours \\
\hline $\begin{array}{l}\text { Metolazone } \\
\text { Potassium-sparing diuretics }\end{array}$ & $2.5 \mathrm{mg}$ once & $20 \mathrm{mg}$ & 12 to 24 hours \\
\hline Amiloride & $5 \mathrm{mg}$ once & $20 \mathrm{mg}$ & 24 hours \\
\hline Spironolactone & 12.5 to $25 \mathrm{mg}$ once & $50 \mathrm{mg}^{*}$ & 2 to 3 days \\
\hline $\begin{array}{l}\text { Triamterene } \\
\text { Sequential nephron blockade }\end{array}$ & 50 to $75 \mathrm{mg}$ twice & $200 \mathrm{mg}$ & 7 to 9 hours \\
\hline Metolazone & \multicolumn{2}{|l|}{2.5 to $10 \mathrm{mg}$ once plus loop diuretic } & \\
\hline Hydrochlorothiazide & \multicolumn{2}{|l|}{25 to $100 \mathrm{mg}$ once or twice plus loop diuretic } & \\
\hline Chlorothiazide (IV) & 500 to $1000 \mathrm{mg}$ once plus loop diuretic & & \\
\hline
\end{tabular}

mg indicates miligrams; IV, intravenous. *Higher doses may occasionally be used with close monitoring. Eplerenone, although also a diuretic, is primarily used in chronic heart failure as a suppressor of the renin-angiotensin-aldosterone system.

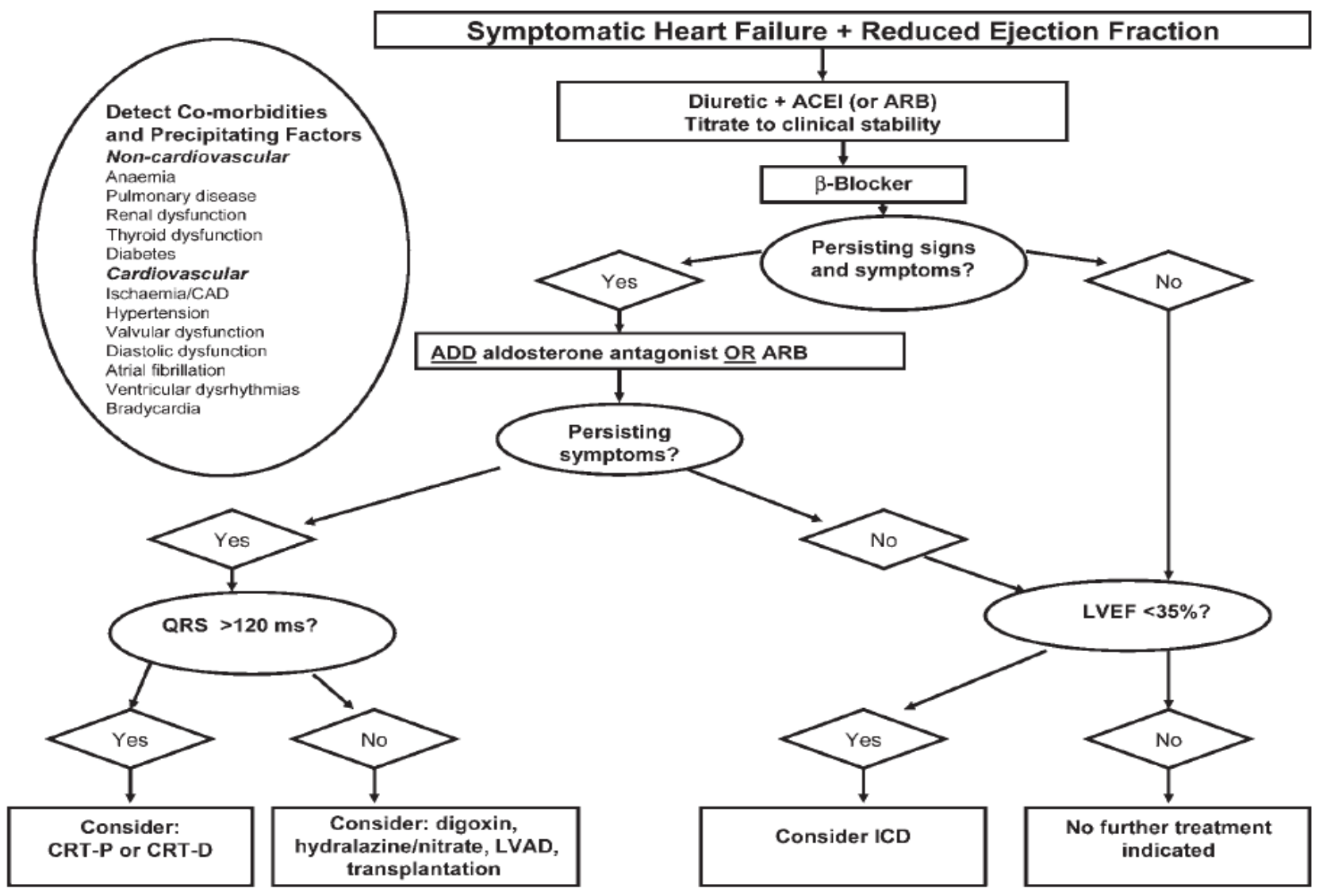

Figure 2. A treatment algorithm for patients with symptomatic heart failure and reduced ejection fraction 
failure in 2010, ensuring that practicioners DON'T go astray from their corridor. The update also mentioned some issues about LVAD (left ventricular assist devices). ${ }^{12}$

\section{Novel therapeutic strategies in heart failure in $\mathbf{2 0 1 1}$}

Recently there are many new management strategies from the year 2011 onward

\section{Anaemia in $\mathrm{CHF}$}

The need for checking haemoglobin and haematinics in patients with $\mathrm{CHF}$, and correcting iron deficiency, where appropriate, was emphasised by the findings in FAIR-HF (Ferinject Assessment in Patients with Iron Deficiency and Chronic Heart Failure), a large multicentre study, which showed benefit in various clinical end-points such as symptom limitation and quality of life, when comparing intravenous iron to placebo. ${ }^{13}$ The use of erythropoietin stimulating agents (ESAs) in CHF is more controversial. Whilst initial studies suggested improvements in LVEF, exercise capacity and quality of life, the randomised clinical trials that followed disappointingly did not show a significant benefit. Results of RED-HF (Reduction of Events with Darbopoetin- $\alpha$ in Heart Failure), a large mortality driven study are eagerly awaited. ${ }^{14}$

\section{Heart rate: the SHIFT study}

Epidemiological and observational studies have shown that an elevated resting heart rate is a risk factor for mortality and poor cardiovascular outcomes. SHIFT (the Systolic Heart failure treatment with $\mathrm{I}_{\mathrm{f}}$ inhibitor Ivabradine Trial) results showed a significant reduction in hospitalisation and death from HF when comparing ivabradine to placebo in patients with advanced HF on optimal therapy. Unsurprisingly, subgroup analysis suggested that those with higher resting heart rates derived greater benefit. ${ }^{15}$

\section{Sleep-disordered breathing}

Sleep-disordered breathing conditions are prevalent in a staggering $50-60 \%$ of HF patients and these conditions can have adverse haemodynamic consequences for the failing heart. Studies have shown that $\mathrm{CHF}$ patients suffering from obstructive sleep apnoea (OSA) treated with continuous positive airway pressure (CPAP) have improved LVEF as well as a significantly reduced risk of death and hospitalisation.

CPAP has not shown any convincing evidence in the management of central sleep apnoea (CSA) associated with CHF, however, adaptive servoventilation (ASV), a novel ventilatory therapy which provides ventilatory support on detection of Cheynes Stokes respiration may have different efficacy. A small randomised study has shown ASV to be of greater benefit than CPAP in treating CSA associated with CHF. ${ }^{16}$ SERVE-HF (Treatment of Sleep Disordered Breathing by Adaptive Servoventilation in HF patients) study, a large trial driven by mortality outcomes is still underway.

\section{Exercise training in heart failure}

The safety and efficacy of exercise training in heart failure as compared to usual-care was evaluated in HF-ACTION (Heart Failure: A Controlled Trial Investigating Outcomes of Exercise Training), a large, multicentre randomised controlled trial. Whilst there was no significant improvement in outcomes, a substudy of the trial did show a significant improvement in patient-reported health status as assessed using the Kansas City Cardiomyopathy Questionnaire. ${ }^{17}$ A small pilot study involving training using electrical muscle stimulation in patients with HF who lead sedentary lifestyles showed that there may be a future role for therapies directed at skeletal muscle to improve $\mathrm{HF}$ symptoms. ${ }^{18}$

\section{Future directions in HF management}

Now the uproar is all about gene therapy in HF. In the first clinical test of a gene therapy for heart failure called CUPID (Calcium Upregulation by Percutaneous Administration of Gene Therapy in Cardiac Disease), administration of a gene that upregulates an enzyme involved in myocardial contraction and relaxation appeared to improve symptoms, functional status, and ventricular volumes in patients with severe systolic heart failure. The treatment entails delivery of a gene associated with an enzyme that is central to controlling the flow of calcium ions between the sarcoplasmic reticulum and cytoplasm and so plays a key role in regulating myocardial contractility. Deficiency of the enzyme, called sarcoplasmic reticulum $\mathrm{CA}^{2+}$ ATPase (SERCA2a), often occurs in advanced heart failure and is considered a mechanism of progressive systolic and diastolic dysfunction. The SERCA2a gene is administered using an adeno-associated viral vector in a single intracoronary dose. ${ }^{19}$

Another interest is the research of stem cell application in HF. Stem cells have an enormous potential to help millions of patients with end-stage ischemic heart failure who have no other therapeutic options. ${ }^{20}$ Both approach will have to wait a while to reach real clinical setting until the second phase trials completed. 
While four major multi-center trials including TELEHF, TIM-HF, TEN-HMS, failed to demonstrate the efficacy of remote telemonitoring systems, evaluation of device-based diagnostics is still underway and looks promising. The CHAMPION trial ${ }^{21}$ randomized 550 patients to therapy guided by an implantable wireless pulmonary artery pressure monitoring system versus standard of care and showed a $28 \%$ reduction in heart failure hospitalizations at 6 months and a $37 \%$ reduction in heart failure hospitalizations over the full duration of follow-up (averaging 15 months). The system used in this study was awaiting CE Mark and FDA approval. An implantable left atrial pressure monitoring system that was preliminarily shown to be effective in a small pilot study $^{22}$ and the pivotal trial of this system, LAPTOP$\mathrm{HF}$, is now underway.

By means of strategy, the uprising of heart failure clinics and one day care will likely be accompanied by a heart failure subspecialty program in the near future. ${ }^{23}$ To combat the pandemic of heart failure in Indonesia, early diagnosis, appropriate evidence based drugs used, new evidence based device in appropriate patients, health insurance coverage, better community health services, health education for compliance in drugs, diet and life style are important. More effort should be emphasis on the prevention program by every health care providers.

\section{REFERENCES}

1. Siswanto BB, Sunanto, Munawar M, Kusmana D, Hanafiah A, Waspadji S, et al. Predictor of mortality and rehospitalization of acute decompensated heart failure at six months follow up. Crit Care \& Shock. 2006;9:61-7.

2. Siswanto BB, Radi B, Kalim H, Santoso A, Suryawan $\mathrm{R}$, Erwinanto, et al. Heart failure in NCVC Jakarta and 5 hospitals in Indonesia. CVD Prevention and Control. 2010;5:35-8

3. Hobbs FD, Doust J, Mant J, Cowie MR. Heart failure: diagnosis of heart failure in primary care. Heart. 2010;96:1773-7.

4. Jimeno Sainz A, Gil V, Merino J, Garcia M, Jordan A, Guerrero L. [Validity of Framingham criteria as a clinical test for systolic heart failure]. Rev Clin Esp. 2006;206:495-8.

5. Dickstein K, Cohen-Solal A, Filippatos G, McMurray JJ, Ponikowski P, Poole-Wilson PA, et al. ESC guidelines for the diagnosis and treatment of acute and chronic heart failure 2008: the task force for the diagnosis and treatment of acute and chronic heart failure 2008 of the European Society of Cardiology. Developed in collaboration with the Heart Failure Association of the ESC (HFA) and endorsed by the European Society of Intensive Care Medicine (ESICM). Eur J Heart Fail. 2008;10:933-89.

6. Hunt SA. ACC/AHA 2005 guideline update for the diagnosis and management of chronic heart failure in the adult: a report of the American College of Cardiology/American Heart Association Task Force on Practice Guidelines (Writing Committee to Update the 2001 Guidelines for the Evaluation and Management of Heart Failure). J Am Coll Cardiol. 2005;46:e1-82.
7. Aronow WS. ACC/AHA guideline update: treatment of heart failure with reduced left ventricular ejection fraction. Geriatrics. 2006;61:22-9.

8. Moss AJ. MADIT-II and its implications. Eur Heart J. 2003;24:16-8.

9. Klein H, Auricchio A, Reek S, Geller C. New primary prevention trials of sudden cardiac death in patients with left ventricular dysfunction: SCD-HEFT and MADIT-II. Am J Cardiol. 1999;83:91D-7D.

10. Cleland JGF, Daubert JC, Erdmann E, Freemantle N, Gras D, Kappenberger L, et al. The CARE-HF study (CArdiac REsynchronisation in Heart Failure study): rationale, design and end-points. Eur J Heart Fail. 2001;3:481-9.

11. Breithardt G. MADIT-CRT (Multicenter Automatic Defibrillator Implantation Trial-Cardiac Resynchronization Therapy): cardiac resynchronization therapy towards early management of heart failure. Eur Heart J. 2009;30:2551-3.

12. Dickstein K, Vardas PE, Auricchio A, Daubert JC, Linde C, McMurray J, et al. 2010 Focused Update of ESC guidelines on device therapy in heart failure: an update of the 2008 ESC guidelines for the diagnosis and treatment of acute and chronic heart failure and the 2007 ESC guidelines for cardiac and resynchronization therapy. Developed with the special contribution of the Heart Failure Association and the European Heart Rhythm Association. Eur Heart J. 2010;31:2677-87.

13. Gonzalez-Costello J, Comin-Colet J. Iron deficiency and anaemia in heart failure: understanding the FAIR-HF trial. Eur J Heart Fail. 2010;12:1159-62.

14. McMurray JJ, Anand IS, Diaz R, Maggioni AP, O'Connor C, Pfeffer MA, et al. Design of the Reduction of Events with Darbepoetin alfa in Heart Failure (RED-HF): a Phase III, anaemia correction, morbidity-mortality trial. Eur J Heart Fail. 2009;11:795-801.

15. Ekman I, Chassany O, Komajda M, Böhm M, Borer JS, Ford I, et al. Heart rate reduction with ivabradine and health related quality of life in patients with chronic heart failure: results from the SHIFT study. Eur Heart J. 2011;32:2395404.

16. Brown LK. Filling in the gaps: the role of noninvasive adaptive servoventilation for heart failure-related central sleep apnea. Chest. 2008;134:4-7.

17. Temporelli PL, Fattirolli F. [The HF-ACTION study]. G Ital Cardiol (Rome). 2010;11:1-5.

18. Banerjee P. Electrical muscle stimulation for chronic heart failure: an alternative tool for exercise training? Curr Heart Fail Rep. 2010;7:52-8.

19. Giacca M, Baker AH. Heartening results: the CUPID gene therapy trial for heart failure. Mol Ther. 2011;19:1181-2.

20. Menasche P. Stem cell therapy for chronic heart failure: lessons from a 15-year experience. C R Biol. 2011;334:48996.

21. Krum H. Telemonitoring of fluid status in heart failure: CHAMPION. Lancet. 2011;377:616-8.

22. Ritzema J, Melton IC, Richards AM, Crozier IG, Frampton C, Doughty RN, et al. Direct left atrial pressure monitoring in ambulatory heart failure patients: initial experience with a new permanent implantable device. Circulation. 2007;116:2952-9.

23. Konstam MA, Jessup M, Francis GS, Mann DL, Greenberg B. Advanced heart failure and transplant cardiology: a subspecialty is born. J Am Coll Cardiol. 2009;53:834-6. 